\title{
Nuclear Factor 1 B-Type
}

National Cancer Institute

\section{Source}

National Cancer Institute. Nuclear Factor 1 B-Type. NCI Thesaurus. Code C38402.

Nuclear factor 1 B-type (420 aa, $47 \mathrm{kDa}$ ) is encoded by the human NFIB gene. This protein is involved in the mediation of both DNA replication and transcriptional regulation. 